\title{
Kurkistuksia miestutkimuksen maailmoihin
}

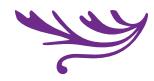

Akateeminen ymmärrys maskuliinisuuteen pohjautuu pitkälle länsimaissa tehtyyn (mies)tutkimukseen, kertovat suomalaistutkijat miestutkimuksen konferenssin kuulumisinaan. Petteri Eerolan esityksen aiheena Kanadassa oli isäksi tulleiden miesten kertomusten suhde isyyden mallitarinoihin. Miestutkimus on maailmalla moni-ilmeistä ja tutkimusongelmat poikkeavat hyvinkin suomalaisista.
\end{abstract}

KUUSITOISTA VUOTTA SITTEN Juha Suoranta kysyi Aikuiskasvatuksen (3/1995) sivuilla: Miestutkimus tulee, oletko valmis (aikuiskasvatus)? Päätimme tarkastella asiaa osallistumalla 9.-11.3.2011 Quebec Cityssä, Kanadassa järjestettyyn kansainväliseen miestutkimuskonferenssiin "Future perspectives for intervention, policy and research on men and masculinities”. Kanadan vanhimmassa Université Laval -yliopistossa järjestettyyn konferenssiin osallistui papereineen yli 200 tutkijaa noin 30 eri maasta. Maantieteellisestä etäisyydestä ja kielestä huolimatta - englannin ohella ranska oli toinen konferenssin pääkielistä - esimerkiksi kaikki pohjoismaat olivat Islantia lukuun ottamatta edustettuina. Kolmen tutkijan "suomalaisdelegaatiomme" sopeutui hyvin Quebecin provinssin pääkaupungin sääolosuhteisiin - lunta, loskaa ja räntää oli yhtä paljon kuin samaan aikaan Suomessakin...

Konferenssin järjestämisestä vastasi kanadalaisista yhteiskuntatieteilijöistä koostuva Masculinities \& Society -tutkijakollektiivi. Yhteiskuntatieteilijöiden ohella konferenssiin osallistui paljon mm. kasvatus- tieteilijöitä, humanisteja ja antropologeja. Eurooppalaisiin tieteellisiin konferensseihin peilattuna erityisen keskeistä oli "kenttäväen" - miestyöntekijöiden, kasvatusammattilaisten, sosiaalialan ammattilaisten jne. - osallistuminen konferenssiin sekä omien papereiden kanssa että aktiivisina keskustelijoina. Sen sijaan, että osallistujat ja sessiot olisivat jakautuneet tutkija/kenttäasiantuntija-luokittelun kautta, keskinäinen vuorovaikutus oli mielekästä ja luontevaa - erityisesti koska quebeciläisistä osallistujista valtaosalla tuntui olevan kokemusta sekä tutkimuksesta että miestyöstä.

Konferenssin ohjelmarunko muodostui sekä plenary-luentojen sijaan järjestetyistä pääpuhujien yhdistetyistä teemapuheenvuoroista ja -keskusteluista (round tables) että perinteisistä työryhmistä (workshops). Sen sijaan että pääpuhujat olisivat koostuneet tunnetuimmista ja viitatuimmista länsimaisista miestutkijoista (esimerkiksi ns. kriittistä miestutkimusta edustavat Raewyn Connell, Michael Kimmel ja Jeff Hearn), kuulimme puheenvuoroja ympäri maailman - pääasiassa tutkijoita useilta eri tieteenaloilta 
edustaneita pääpuhujia oli vähintään yksi jokaisesta maanosasta.

Suomalaisesta näkökulmasta katsottuna käsiteltyjen teemojen ja kysymysten kirjo oli ilahduttavan suuri ja laaja-alainen. Keskeisimmät teemat pyöreän pöydän esitelmissä ja puheenvuoroissa olivat muun muassa paljon keskustelua herättäneen ja monelta taholta kritisoidun maskuliinisuus-käsitteen laajaalainen teoreettinen ymmärtäminen, miesten terveys, miehet ja maskuliinisuudet ympäri maailman ja miehuuden sosiaalipolitiikat. Työryhmissä käsiteltiin muun muassa maskuliinisuuden eriäviä muotoja, isiä, poikia, miesten tekemää ja kohtaamaa väkivaltaa, miesten seksuaalisuutta ja seksuaalisia vähemmistöjä sekä miesten työntekoa että poikien koulutusta. Teoreettisten ja tutkimusta käsittelevien tarkastelujen lisäksi työryhmissä esiteltiin useita interventioita ja mies-, isyys- ja poikatyön käytännön sovelluksia. Omat esitelmät pidimme työryhmissä "Father involvement" ja "Boys and school" - Petteri tarkasteli suomalaisten ensi kertaa isäksi tulleiden miesten kertomusten suhdetta isyyden mallitarinoihin ja Minna käsitteli 11-12-vuotiaiden poikien kokemuksia perhesuhteista ja perhesuhteiden vaikutusta poikien kokemaan emotionaaliseen turvallisuuteen.

\section{MASKULIINISUUDESTA KÄSITTEENÄ}

Maskuliinisuuksien teoreettisissa tarkasteluissa peräänkuulutettiin maskuliinisuus-käsitteen laajaalaisemman ymmärryksen perään. Ns. kriittisen miestutkimuksen kansainvälisesti suurimman ja tunnetuimman tieteellisen yhdistyksen AMSAn (American Men's Studies Association) puheenjohtajan Robert Heasleyn mukaan ymmärtääksemme maskuliinisuuksia laajemmin tarkastelun fokus tulee siirtää marginaaliin - on tarkasteltava ja etsittävä uusia, yllättäviä ja kuvitteellisesta normista poikkeavia tapoja olla mies. Tämä voi tarkoittaa esimerkiksi sekä implisiittisten maskuliinisuus-käsitysten purkamista (esimerkiksi fyysisesti voimakas, rationaalinen, heteroseksuaalisesti suuntautunut, valkoihoinen jne.) että kriittisten kysymysten esittämistä, kuten kuka on tai voi olla mies tai mikä tekee yksilöstä miehen. Heasley painotti, että ymmärrys maskuliinisuudesta tulee rakentaa uudelleen aiempaa moniulotteisem- maksi ja vähemmän normatiivisemmaksi - erilaisten maskuliinisuuksien tunnustaminen on tärkeää tasa-arvonäkökulman lisäksi myös inhimillisyyden ja hyvinvoinnin nimissä.

Maskuliinisuuden käsitteellistä ymmärrystä pohtivia puheenvuoroja jatkoi Leedsin Metropolitanyliopiston hoitotieteen professori Steve Robertson, joka kysyi, onko maskuliinisuuden käsite tullut tiensä päähän. Robetsonin kysymys pohjautui käsitettä kohtaan esitettyyn laajaan kritiikkiin. Hänen mukaan diskursseissa esiintyvä maskuliinisuus ymmärretään usein samanlaisena kaikille miehille ja Jeff Hearniin viitaten toteaa, kuinka maskuliinisuuden käsitteellä validioidaan erot miesten ja naisten toiminnassa. Robertson korostaa, että maskuliinisuuksia tulisi ymmärtää pikemminkin dynaamisina konfiguraatioina, jotka vaihtelevat ajan, paikan ja sosiaalisen todellisuuden suhteen. Raewyn Connellia mukaillen hän korostaa myös maskuliinisuuksien hierarkkisia suhteita, joita esimerkiksi eri instituutiot ja sosiaaliset rakenteet hyväksyvät. Tämä tarkoittaa, että maskuliinisuutta tuleekin tarkastella sosiaalisena ilmiönä eikä vain yksilöllisenä piirteenä.

\section{MASKULIINISUUDEN PARADIGMAT}

Kenties konferenssin mielenkiintoisin teoreettista tarkastelua hakeva esitys oli Université du Québec -yliopiston sosiaalityön professori Sacha Genest Dufaultin Five paradigms to understand men and masculinities: A proposal for an original classification, jossa hän hahmotteli kokonaiskuvaa maskuliinisuuden paradigman kehityskulusta. Aiemmin vastaavaa kronologisointia on esittänyt mm. Raewyn Connell Masculinities-teoksessaan, joka vaikuttaa myös Dufaultin tulkinnan taustalla.

Dufaultin mukaan maskuliinisuuden teoreettisen ymmärryksen viisi keskeistä (ja kronologisesti etenevää) vaihetta ovat 1 . biologinen, 2 . identiteettiä korostava, 3. normatiivinen, 4. rakenteellinen ja 5. performatiivinen paradigma. Biologisen paradigman korostaessa miesten biologista eroa naiseen (esimerkiksi mies fyysisesti vahvempana), identiteettiparadigma korostaa sukupuolten välisiä psyykkisiä eroja (esimerkiksi mies rationaalisempana yksilönä). Normatiivinen paradigma painottaa sukupuoliroolien 
normittavaa luonnetta (esimerkiksi miesten toimittava "kuten mies") ja rakenteellinen paradigma maskuliinisuuksien monimuotoisuutta, suhteellisuutta ja tilannesidonnaisuutta (esimerkiksi "tilanteen mukaan joustava maskuliinisuus").

Vaikka edellä mainituilla tulkinnoilla on yhä kannattajansa, Dufaultin mukaan nykyparadigmaa edustaa Judith Butleria lainaava performatiivinen paradigma, joka korostaa sukupuolirooleja performatiivisina diskursseina (jolloin "miestä esitetään"). Dufaultin tulkinta voidaan hahmottaa myös erilaisina ikkunoina miehisyyteen, jotka kaikki ovat yhä nyky-yhteiskunnassa läsnä, erilaisin painotuksin ja ymmärryksin ajasta, paikasta ja tilasta riippuen.

\section{MIEHET JA TERVEYS}

Miesten terveyttä käsittelevissä puheenvuoroissa korostuivat mm. yhteiskunnan ja kulttuurin vaikutus miesten terveyskäyttäytymiseen sekä käsitykseen omasta terveydestään että avun tarpeesta. Western Sydney -ylipiston terveystieteiden professorin John Macdonaldin mukaan maskuliinisuus-käsityksillä selitetään ja syrjäytetään sosiaaliset ja poliittiset tekijät, jotka voivat vaikuttaa miesten huono-osaisuuteen. Macdonaldin mukaan miesten terveyttä tutkiessa täytyy ottaa huomioon esimerkiksi sosiaalinen ympäristö, jossa miehet elävät ja työskentelevät.

Yhdysvaltalaisen Clarck-yliopiston psykologian professori Michael E. Addisin mukaan amerikkalaisilla miehillä on naisia korkeampi itsemurhariski, miehet käyttävät naisia enemmän päihteitä ja ovat haluttomampia pyytämään apua tarvittaessa. Addisin mukaan sukupuolten sosiaaliset konstruktiot vaikuttavat muun muassa sekä siihen kuinka sairautta koetaan ja tunnetaan että kuinka siitä kerrotaan. Lisäksi hän myös korostaa, kuinka sukupuoliroolit vaikuttavat sekä käsityksiin että kokemuksiin oppimisesta ja koulutukseen osallistumisesta - toistaiseksi esimerkiksi Suomessa sukupuolten välisiä koulutuseroja ei ole tarkasteltu tästä näkökulmasta.

Se, että konferenssiin osallistui tutkijoiden lisäksi huomattavasti myös miesten parissa työskenteleviä "kenttätyöntekijöitä", näkyi työryhmäesitelmissä. Miesten terveys -teemaan liittyen keskustelua herättivät myös mm. kysymykset siitä, kuinka esimerkik- si terveydenhuolto-organisaatiot työntekijöineen pystyisivät ymmärtämään paremmin vaikkapa kulttuurillisten maskuliinisuuksien vaikutuksia miesten terveyskäyttäytymiseen. Esimerkkinä voidaan pohtia tilannetta, jossa terveydenhuollossa vallitsee sekä yksilöllisellä että organisaatio-tasolle käsitys siitä, että yksittäisen miehen vastahankainen asenne terveydenhuoltoa kohtaan on selitettävissä yksilöllisillä tekijöillä, vaikka syyt voivat löytyä myös vallitsevista maskuliinisuuskäsityksistä. Tällaisia maskuliinisuuskäsityksiä on esimerkiksi se, millaista hoitoa ja apua tietyssä kulttuurissa elävä mies on kykeneväinen ja valmis vastaanottamaan. Näyttää siltä että sekä tutkimus- että miestyötä ymmärtävien sillanrakentajien - jollaiseksi kyseinen konferenssi voidaan nähdä merkitys tiedonrakentajina korostuu, kun pohditaan esimerkiksi, kuinka miesten aktiivista osallistumista terveydenhuoltopalveluihin voitaisiin helpottaa tai kuinka terveydenhuoltohenkilökuntaa voitaisiin ohjata tunnistamaan sukupuoliroolien vaikutusta miesten terveyskäyttäytymiseen.

\section{LÄNSIMAINEN KÄSITYS DOMINOI}

Länsimaista viitekehystä laajempi lähestyminen maskuliinisuuksiin oli yksi konferenssin keskeisiä teemoja. Pääpuhujista Gilles Tremblay Lavalin yliopistosta korosti, kuinka akateeminen ymmärrys maskuliinisuudesta pohjautuu pitkälti länsimaissa tehtyyn (mies) tutkimukseen. Kuitenkin ymmärtääksemme maskuliinisuutta laajemmin tutkijoiden tulee ottaa huomioon erilaiset sosiaaliset ja kulttuuriset todellisuudet. Myös Juan Carlos Ramirez Rodriguez Guadalarajan yliopistosta Meksikosta ja Sanjay Singh M.G. Kashi Vidyapath-yliopistosta Intiasta korostivat maskuliinisuuksien tarkastelua kriittisessä valossa.

Singhin mukaan intialaisten miesten on vaikeaa täyttää ympäristönsä heihin kohdistamat miehenä olemisen vaatimukset. Voidaan myös kysyä, kuinka tämä eroaa esimerkiksi suomalaisten miesten ja poikien todellisuudesta, jossa huono-osaisuus ja pahoinvointi ovat sukupuolittuneet.

Myös Masculinities around the world -työryhmän paperit lähestyivät maskuliinisuuksia paikalliselta tasolta. John Crownover CARE International -järjestöstä tarkasteli Balkanin alueen poikien ongelmia 
sukupuoliroolien, terveyden ja väkivallan alueilla ja Scott North Osakan yliopistosta pohti esitelmässään japanilaisten miesten kyvyttömyyttä työn ja perheen yhteensovittamiseen. Färsaarelainen antropologi Firouz Gaini (University of the Faroe Island) käsitteli esitelmässään maskuliinisuuden muutosta sankaritarinoiden muutoksen kautta, Uumajan yliopiston Isabel Goicolean ja Ann Ohmanin tarkastellessa ecuadorilaisten nuorten miesten maskuliinisuus-käsitysten muutosta perinteisestä "machismo"-kulttuurista kohti tasa-arvoisempia ja moninaisempia tapoja olla mies.

\section{KASVATUS JA AIKUISKASVATUS MARGINAALISSA}

Kuten myös suomalaisissa sukupuolentutkimuskonferensseissa, kasvatus- ja aikuiskasvatukselliset kysymykset olivat marginaalissa. "Boys and school" -työryhmästä huolimatta esimerkiksi kysymykset miesten osallistumisesta koulutukseen jäivät tyystin käsittelemättä. Suomalaisesta näkökulmasta teema on kuitenkin mielenkiintoinen, sillä suomalaisten koulutustaso on noussut, muttei tasaisesti - esimerkiksi naisten osuus korkeakoulutetuista on kasvanut huomattavasti miesten osuutta suuremmaksi. ${ }^{1}$ Vaikka asiasta on puhuttu paljon, kysymykset sukupuoliroolien vaikutuksesta tuntuvat suomalaiskeskustelusta unohtuneen. Olisikin ollut mielenkiintoista tietää, miten ja millaisia keskusteluja miesten koulutuksesta muualla maailmassa käydään.

Mitä konferenssi tarjosi kahdelle väitöstutkimuksensa ensimmäisellä puoliskolla olevalle tohtorikoulutettavalle? Sen lisäksi, että pääpuhujien puheenvuorot ja työryhmäkeskustelut olivat inspiroivia ja herättivät paljon uusia kysymyksiä, keskeinen merkitys konferenssimatkalle syntyi tutkijayhteisöön kuulumisen ja osallistumisen kautta. Koska mies-, isyys- ja poikatutkimuksen tutkijakunta on Suomessa hyvin pientä, oli hienoa tavata ja tutustua samoista kysymyksistä kiinnostuneisiin kollegoihin ympäri maailmaa - kansainvälistä verkostoitumista siis. Esimerkiksi, saimme molemmat useita hyödyllisiä kontakteja, joista on todennäköisesti sekä iloa että hyötyä myös tutkijauralla. Myös omista esitelmistä saamamme positiivinen palaute - sekä hyödylliset vinkit että kriittiset kehitysehdotukset - olivat tärkeitä kansain- välistä uraa aloitteleville tutkijoille. Suomalaisittain tuttuihin tieteellisiin konferensseihin peilattaessa oli sekä mielenkiinoista että opettavaista osallistua konferenssiin, jossa teoria ja käytäntö vuorottelivat. Myös näin voi tehdä.

Ja entä vastaus Suorannan esittämään kysymykseen? Näyttää siltä, että ainakaan vielä miestutkimus ja aikuiskasvatus niin Suomessa kuin kansainvälisestikään eivät ole toisiaan löytäneet. Epäilemme, että kysymys olisi siitä, ettei aikuiskasvatus taipuisi miestutkimuksellisiin teemoihin tai toisinpäin. Tärkeää olisikin, että sukupuolikysymyksiä - sukupuoleen katsomatta - ei aikuiskasvatuksen piirissä siirrettäisi syrjään, vaan jopa "kaivettaisiin ne esille". Sama koskee sukupuolentutkimusta. Aikuiskasvatuksellinen ymmärrys kasvusta, kehityksestä ja oppimisesta voi tarjota avartavia näkökulmia myös sukupuoliteemoihin. Tämä kaikki yhdistettynä teorian ja käytännön sulavaan vuoropuheluun - kuka ottaisi ideasta kopin?

Future perspectives for intervention, policy and research on men and masculinities, Quebec City, Canada, March 09-11, 2011 http://www.criviff.ulaval. ca/masculinites_societe/colloque_masculinites_ societe/en/

\section{Väliotsikot toimituksen}

${ }^{1}$ http://www.stat.fi/artikkelit/2009/art_2009-0930_001.html

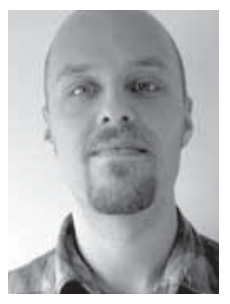

Petteri Eerola

KM, tohtorikoulutettava Kasvatustieteiden laitos Jyväskylän yliopisto

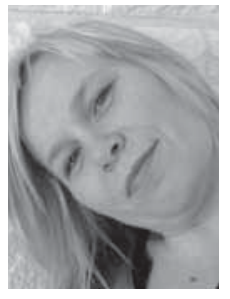

Minna Harju-Veijola KM, tohtorikoulutettava Yhteiskuntatieteiden tiedekunta Jyväskylän yliopisto 